\title{
Determination of the Relationship Among Cell Proliferation, Metabolic Activity and Stage of Pregnancy by AgNORs as Markers in Bovine Placenta
}

\author{
Determinación de la Relación entre la Proliferación Celular, la Actividad Metabólica \\ y la Etapa de Preñez por los AgNOR como Marcadores en la Placenta Bovina
}

\author{
Patrícia dos Santos Carneiro; Tais Harumi de Castro Sasahara; Hianka \\ Jasmyne Costa de Carvalho; Maria Angélica Miglino \& Silvio Pires Gomes
}

CARneiro, P. DOS S.; SASAhara, T. H .C.; CARVAlHO, H. J. C.; MiglinO, M. A. \& GOMES, S. P. Determination of the relationship among cell proliferation, metabolic activity and stage of pregnancy by AgNORs as markers in bovine placenta. Int. J. Morphol., 39(5):1358-1364, 2021.

SUMMARY: Nucleolus Organizer Regions (NORs) are defined as nucleolar components containing argyrophilic proteins selectively stained by silver methods (AgNORs). Several investigations have shown the AgNOR quantity and area represent a valuable parameter of cell kinetics, since they reflect the level of activity and cellular proliferation. This article addresses an evaluation of the functional activity and relation between days of pregnancy and proliferative capacity of trophoblastic mononucleate and binucleate cells from bovine placentomes. Both the number and size of AgNORs were determined in different phases of gestation by silver nitrate staining in conventional histological slides. The results showed a significant increase (from 1 to $12 \mathrm{AgNORs)} \mathrm{in} \mathrm{the} \mathrm{number} \mathrm{of} \mathrm{AgNORS}$ per trophoblastic mononucleate cell in the 3rd trimester, with predominance of 4-6 AgNORs/cell. In the 1st and 2nd trimesters, the number ranged between 1 and 9 AgNORs/cell, with predominance of 1-3 AgNORs. No significant differences were observed between the 2nd and 3rd trimesters, but in the first, in binucleate cells (19-27 and 10-18 AgNORs/cell, respectively) - this number was higher than the one registered in trophoblastic mononucleate cells in the same period. Thus, AgNORs can be used as markers of the proliferative placental cell cycle and established a relation between number of AgNORs and days of gestation. This relation can be used for diagnoses and prognoses of several placental pathologies, including pregnancy losses from manipulated embryos.

KEY WORDS: Nucleolar organizer regions; Placenta; Cellular structures; Pregnancy.

\section{INTRODUCTION}

Nucleolar Organizer Regions (NORs) were first described by Heitz (1931) and McClintock (1934) as regions of lightly colored chromatin around which, at the end of the telophase, the nucleolus is formed again after its disappearance in the cell's mitotic phase.

NORs are made of rDNA cistrons (clusters) that normally form one or more nucleoli. However, in some situations, they are sprayed inside the nucleus, in the form of dots (dots), or in modified forms (Goodpasture \& Bloom, 1975).

A peculiar group of acid proteins of high affinity for silver is located in the same region of NORs, and can be clearly and quickly visualized by colorings with the use of silver nitrate (Goodpasture \& Bloom).
When stained by silver, NORs can be easily identified as black dots of larger or smaller size, exclusively located in the nucleolar area and called AgNORs (Treré 2000). They are structural-functional units in the nucleolus where all components necessary for the synthesis of ribosomal RNA are located. Their number is closely related to the transcriptional activity of RNAr and agility and speed of cell proliferation in the tissue studied (Derenzini et al., 1989).

The number and size of NORs significantly vary within the nucleolus, according to the RNAr's transcriptional activity. Each silver-colored dot (DOT) corresponds, at the ultrastructural level, to the fibrillar center in close association with the dense fibrillar component (Derenzini et al., 1990; Derenzini \& Ploton, 1991). 
CARNEIRO, P. DOS S.; SASAHARA, T. H .C.; CARVALHO, H. J. C.; MIGLINO, M. A. \& GOMES, S. P. Determination of the relationship among cell proliferation, metabolic activity and stage of pregnancy by AgNORs as markers in bovine placenta. Int. J. Morphol., 39(5):1358-1364, 2021.

Binucleated cells are formed through caryocene processes not followed by citicines, that is, there is a duplication of the nucleus without cytoplasm division (Bjorkman, 1982). Its nuclear division is terminated by mitosis and cytoplasm division never occurs, which demonstrates its proliferative incapacity (Winsatt, 1980).

Silver staining has been widely used in the diagnosis and prognosis of several types of tumors; it efficiently characterizes cell proliferation, since cancer cells have a large amount of AgNORs, whereas cells from benign or normal lesions have a smaller number (Derenzini et al., 1989). However, the rate of cell proliferation of malignant tumors is not always higher than that of normal cells or benign tumors.

Few studies on non-tumor tissues have been developed - especially regarding trophoblastic tissue, some refer to tissues from abortions (hydrops, complete or partial hydatidiform mole) (Suresh et al.,1990; Neudeck et al., 1997), but no reference related to normal tissue has been found.

Trophoblastic cells are divided into two large populations, namely mononucleated and binucleated cells, which account for approximately one fifth of the total population. They produce several hormones and growth factors associated with fetal growth and maintenance of pregnancy (Schlafer et al., 2000).

The development of the tetraploid nucleus can be explained by two subsequent cellular dynamics mitoses in the life history of its TGC dinucleotide (Klisch et al., 1999a,b).

The invasion of trophoblasts during placental formation includes several stages. In these stages, trophoblast cells enter different cell types and may invade different areas of the uterine wall. The population of trophoblastic cells differs in the depth of penetration into the uterine wall and in the form of invasion. In rodents, trophoblastic cells that undergo embryonic implantation produce large primary trophoblastic cells (PGTC), which dissolve the epithelium of the endometrium and migrate from time to time (AlAbbass \& Schultz, 1966).

The NOR interface uses rRNA synthesis. All the necessary components of the rib the body's transcription are located within the NORs limit: the rRNA genes are completely in the non-nucleosomal stage. The extended structure (a configuration, which is ready for transcription), RNA polymerase I, RNA polymerase I and topoisomerase I (Derenzini et al., 1990).
There is evidence that in cells in proliferation AgNOR between the nucleolar protein and the nuclear phosphorescent protein, has gradually increased since the beginning of phase G1, reaching the maximum value at the end of phase $S$ and remains constant until the end of $\mathrm{G} 2$.

Of particular interest is the discovery of the AgNOR interphase number and cells proliferate rapidly. It has been proven that in human's tumor cell lines of different origins cultivated in vitro are shorter the greater the amount of time the AgNORs cell doubles (Trerè et al., 1989; Derenzini et al., 1990; Ofner et al., 1992; Derenzini et al., 1995). Вy studying the relationship between the amount of interphase AgNOR and the doubling time of the tumor, these data are confirmed in vivo xenotransplantation of human cancer cells in thymus mice (Trerè et al., 1997).

Considering the growth of both placenta and mono and binucleated trophoblastic cells, this study aimed to determine a quantitative relationship between cell proliferation and stage of pregnancy through AgNORs (used as markers in bovine placentas) quantification and highlight an intense proliferative and metabolic activity of binucleated cells. The standard of normality was established for bovine pregnancies for their comparison with abnormal pregnancies or those from embryos manipulated in the laboratory.

\section{MATERIAL AND METHOD}

Five samples of bovine placentomes from the first trimester of pregnancy, 9 samples from the second trimester, and 7 from the third trimester were collected from the uterus of slaughterhouse pregnant horns positioned dorsally to the fetus, immediately after the uterus had been removed. They were then cut into cubes of approximately $0.5 \mathrm{~cm}$, packed in a bottle with $10 \%$ buffered formaldehyde, and fixed for 24 hours. The material inclusion process, which consists of an increasing series of alcohols for dehydration, xylol for clarification and later inclusion in paraffin, was initiated. The slides were prepared in duplicate, and the cuts were placed in an oven at $560 \mathrm{C}$ for complete fixation and beginning of dewaxing. The process was completed with the immersion of the slides in xylol and the decreasing series of alcohols for rehydrating the cuts. The first slides were stained with Hematoxylin-Eosin (HE), for correct tissue evaluation. A pair of slides was stained with Silver Nitrate (AgNO3), where the cuts were immersed in a final 1:2 solution consisting of colloidal solution (gelatin $2 \%$ and formic acid $1 \%$ ) and silver nitrate solution (1:1). The slides were then placed in the oven at $37 \mathrm{oC}$ in a humid chamber, where they remained for approximately 20 minutes. After 
CARNEIRO, P. DOS S.; SASAHARA, T. H .C.; CARVALHO, H. J. C.; MIGLINO, M. A. \& GOMES, S. P. Determination of the relationship among cell proliferation, metabolic activity and stage of pregnancy by AgNORs as markers in bovine placenta. Int. J. Morphol., 39(5):1358-1364, 2021.

washing with water, the $1 \%$ sodium thiosulfate solution was applied for one minute and a new wash was performed. The slides were dried at room temperature. The capture and digitalization of the images and subsequent counting of AgNORs were performed under an optical microscope (Leitz Diaplan) of 400X magnification, in CCD-IRIS Sony Company system. A statistical analysis involving nonparametric t-Student and One-way ANOVA tests for $\mathrm{p}=0.05$ and a Tukey's multiple comparisons test were then conducted.All animals' experiments were made in accordance with ARRIVE guidelines and national and international laws of animal protection.

Ethics approval. The present work was approved by Ethics Committee on Animal Using and received the number 330/ 200 .

Table I. Mononucleated bovine placentonium trophoblastic cells in different trimesters of pregnancy (\%) and number of AgNORs.

\begin{tabular}{lcccc}
\hline AgNORs & 1 a 3 & 4 a 6 & 7 a 9 & $>9$ \\
\hline $1^{\circ}$ trimester & $26,1 \pm 9,7$ & $6,0 \pm 0,9$ & $1,6 \pm 0,9$ & $0,4 \pm 0,0$ \\
$\mathrm{n}=5$ & & & & \\
$2^{\circ}$ trimester & $24,9 \pm 13,0$ & $12,0 \pm 6,9$ & $1,6 \pm 1,3$ & $1,3 \pm 0,5$ \\
$\mathrm{n}=9$ & & & & \\
$1^{\circ}$ trimester & $8,9 \pm 8,9$ & $16,6 \pm 8,9$ & $7,3 \pm 6,3$ & $3,7 \pm 3,5$ \\
$\mathrm{n}=7$ & & & & \\
\hline
\end{tabular}

Table II. Binucleated trophoblastic cells of bovine placentonium in different trimesters of pregnancy (\%) and number of AgNORs.

\begin{tabular}{|c|c|c|c|c|}
\hline AgNORs & 10 a 18 & 19 a 27 & 28 a 36 & $>36$ \\
\hline $\begin{array}{l}1^{\circ} \text { trimester } \\
\mathrm{n}=5\end{array}$ & $2,4 \pm 0,4$ & $1,4 \pm 0,9$ & $0,0 \pm 0,0$ & $0,0 \pm 0,0$ \\
\hline $\begin{array}{l}2^{\circ} \text { trimester } \\
\mathrm{n}=9\end{array}$ & $3,5 \pm 1,3$ & $4,6 \pm 1,8$ & $2,2 \pm 0,3$ & $0,0 \pm 0,0$ \\
\hline $\begin{array}{l}1^{\circ} \text { trimester } \\
\mathrm{n}=7\end{array}$ & $4,0 \pm 2,5$ & $5,0 \pm 1,2$ & $3,2 \pm 2,0$ & $2,3 \pm 0,9$ \\
\hline
\end{tabular}

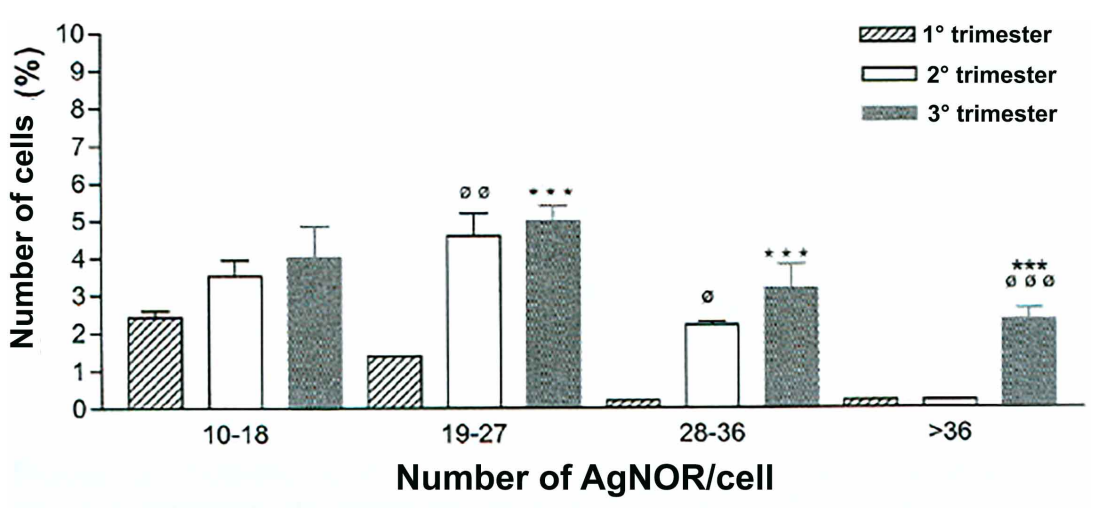

$ø$ difference between the first and second trimester

* difference between the first and third trimester

$\because * p<0.05$ :

$\circ, \cdots: p<0.01$ :

$\ldots, \cdots: p<0,001$

\section{RESULTS}

The total number of AgNORs (dots and clusters) expressed by mononucleated trophoblastic cells in the three trimesters of pregnancy was analyzed. The quantities of AgNORs per cell (1-3, 4-6, 7-9 and >9) were grouped so as to characterize the trimesters. The first and second trimesters displayed a similar behavior regarding number of predominant AgNORs/ cell, since most of the counted cells showed 1 to 3 AgNORs (26.1 \pm 9.7 and $24.9 \pm 13.0$, respectively), significantly differing $(\mathrm{p}<0.05)$ from the quantity found in the third trimester (8.9 9.0). Cells with 4 to $6 \mathrm{AgNORs}$ were the most in the third trimester $(16.6 \pm 8.9)$, with a significant

difference $(\mathrm{p}<0.05)$ in relation to the first trimester $(6.0 \pm 3.8)$, but not to the second quarter $(12.1 \pm 6.9$, $\mathrm{p}>0.05)$. An analysis of larger amounts of AgNORs per cell ( 7 to 9 ) revealed a continuous larger number of cells $(7.3 \pm 6.3)$ in comparison to the first and second trimesters (1.61-0.9 and 1.6 \pm 1.3 , respectively), which is a significant difference $(\mathrm{p}<0.05)$ (Table I; Fig. 1).

The total number of AgNORs (dots and clusters) expressed by binucleated trophoblastic cells was also analyzed in the three trimesters of pregnancy. Once again, the quantities of AgNORs found per cell were grouped (10-18, 19-27, 28-36 and >36) for characterizing the trimesters. (Fig. 3).

The first interval evaluated (10 to 18 AgNORs/ cell) showed no significant differences among the three trimesters; however, this was the interval in which most cells in the first trimester were $(2.4 \pm 0.4)$. The second interval (19 to $27 \mathrm{AgNORs} / \mathrm{cell})$ showed a significant difference $(\mathrm{p}<0.01)$ between the first $(1.4$ $\pm 0.0)$ and the second trimesters (4.6 \pm $1.8)$ - the difference was even larger $(\mathrm{p}<0.001)$ between the first and the third trimesters (5.0 1 1.2). Moreover, most binucleated cells in the second and third trimesters were in this range. Similar results were found for the third analysis interval (28 to $36 \mathrm{AgNORs} /$ cell), with the first trimester $(0.2 * 0.0)$ significantly differing $(p<0.05)$ from the second $(2.2$

Fig. 1. Distribution of mononucleated bovine placentonium trophoblastic cells according to the trimesters of pregnancy and number of AgNORs per cell. 
CARNEIRO, P. DOS S.; SASAHARA, T. H .C.; CARVALHO, H. J. C.; MIGLINO, M. A. \& GOMES, S. P. Determination of the relationship among cell proliferation, metabolic activity and stage of pregnancy by AgNORs as markers in bovine placenta. Int. J. Morphol., 39(5):1358-1364, 2021.

$\pm 0.3)$ - the difference was larger $(\mathrm{p}<0.001)$ in relation to the third trimester (3.2 12.0 ). A comparison among the trimesters for the last interval (>36 AgNORs/cell) revealed significant

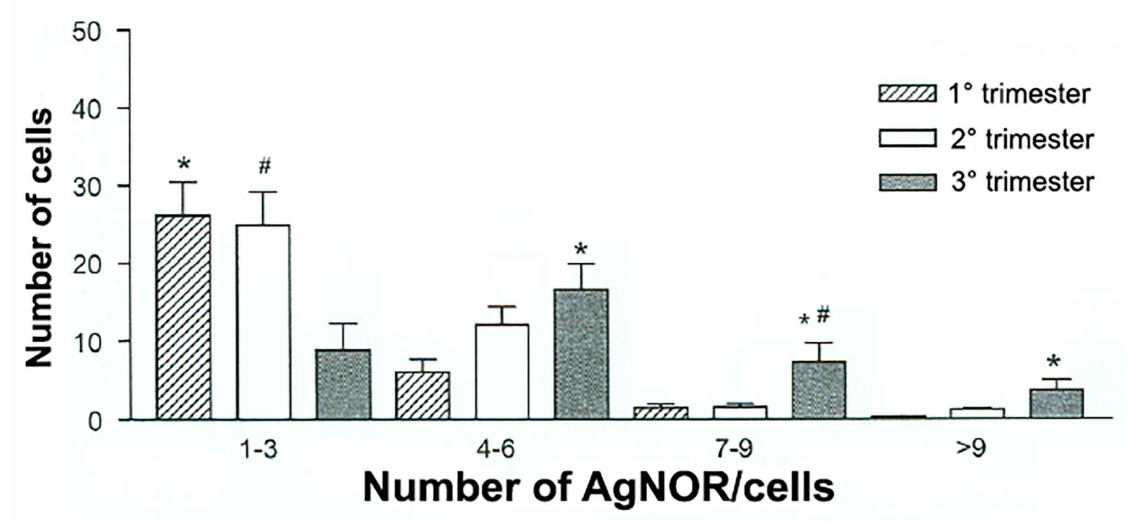

* difference between the first and third trimester

\# difference between the second and third trimester

* or \#: $p<0,05$
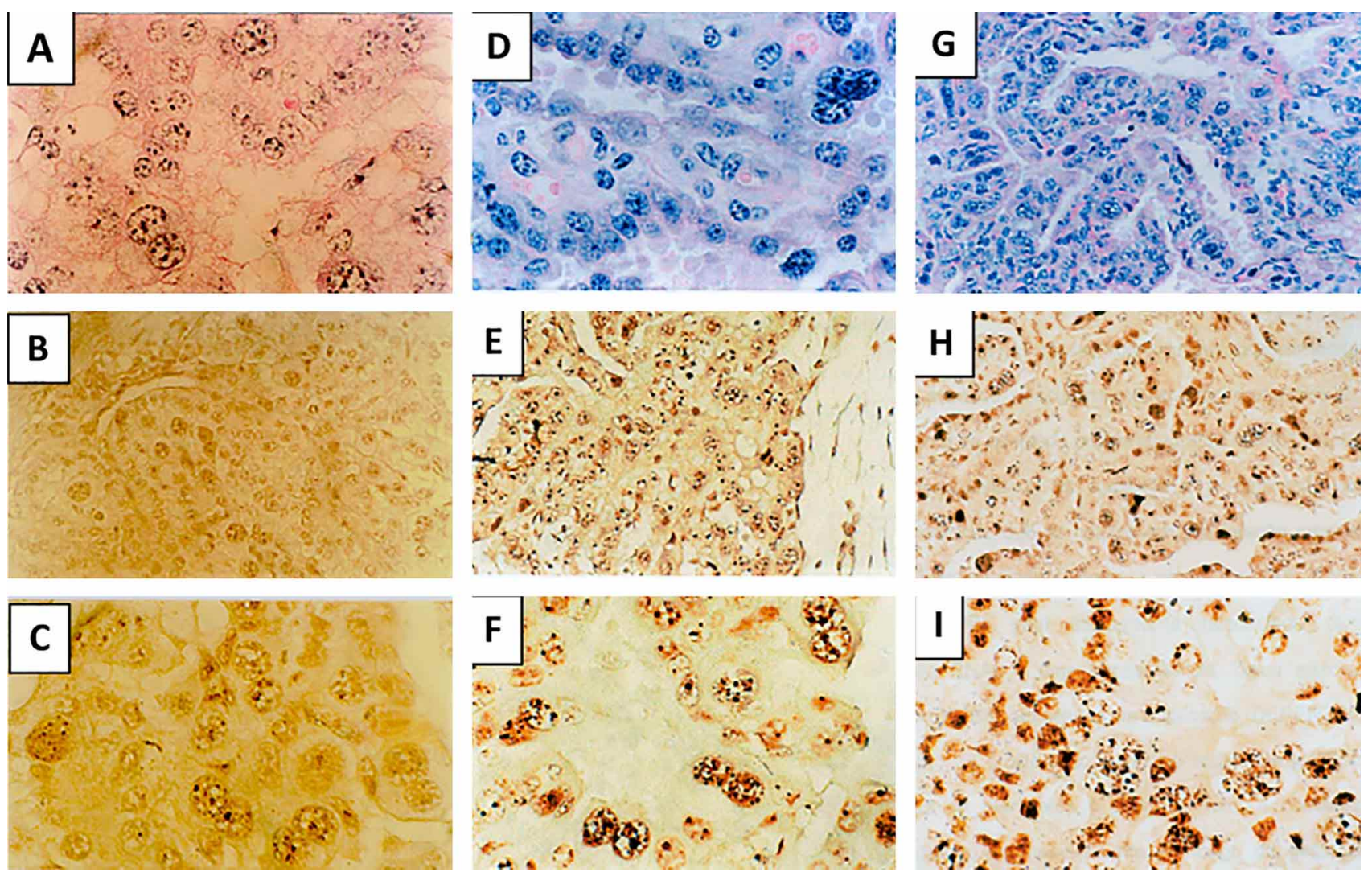

Fig. 3. Photomicrographs of histological sections of bovine placentones, first trimester of pregnancy. Figures (B) and (C) show intranuclear black dots that represent AgNORs. (A) 100X magnification, hematoxylin-eosin (HE) staining; (B) 40X magnification, silver nitrate staining (AgNO,); (C) 100X magnification, silver nitrate (AgNO) staining. Photomicrographs of histological sections of bovine placentals, second trimester of pregnancy. Figures (E) and (F) show intranuclear black dots that represent AgNORS. (D) 100X increase in hematoxylineosin (HE) staining; (E) 40X magnification, silver nitrate staining (AgNO3): (F) 100X magnification, silver nitrate staining (AgNO3). Photomicrograph of bovine placenton, third trimester of pregnancy. Figures $(\mathrm{H})$ and $(\mathrm{I})$ show intranuclear black dots that represent AgNORs (G) 40x magnification. Hematoxylin-eosin staining (H.E.) (H) 40x increase silver nitrate staining and (I) $100 \mathrm{X}$ increase. 
CARNEIRO, P. DOS S.; SASAHARA, T. H .C.; CARVALHO, H. J. C.; MIGLINO, M. A. \& GOMES, S. P. Determination of the relationship among cell proliferation, metabolic activity and stage of pregnancy by AgNORs as markers in bovine placenta. Int. J. Morphol., 39(5):1358-1364, 2021.

\section{DISCUSSION}

Variations in the amount of AgNORs depend on cell activity (Leek et al., 1991), and several studies have shown they represent a valid parameter for cell kinetics closely associated with the agility of cell duplication (Derenzini et al., 1989; Treré et al., 1989; Derenzini et al., 1990, 1995). Our results confirmed an increase in the amount of AgNORs in mononucleated trophoblastic cells especially in the third trimester of pregnancy, which indicates an increase in their proliferative and/or metabolic capacity. The relationship between the amount of AgNORs and cell duplication results from the production of a ribosomal complement by the proliferating cells, suitable for daughter cells. Since the number of AgNORs is closely related to the transcriptional activity of RNAr, it is consequently associated with cells in duplication (Derenzini, 2000). The increase in cell proliferation is easily justified, i.e., in many species of mammals, the weight of the fetus and its placenta increases exponentially throughout the gestation (it is more evident in the last months (Evans \& Sack, 1973; Ferrell et al., 1976). A positive correlation between fetal weight and placental weight has been described for several species (Ibsen, 1928; Warwick 1928). Reynolds et al. (1990) reported the gain in the weight of caruncle (maternal tissue) was 2 to 4 times greater than that of cotyledon (fetal tissue) in the last two trimesters of pregnancy. However, the concentration of caruncular DNA remained relatively constant from day 100 to day 250, whereas the amount of cotyledonary DNA increased, indicating the cell density in cotyledons increased throughout pregnancy, although their absolute mass increased more slowly than that of caruncle (Baserga, 1985; Reynolds et al.).

Since such cells, together with binucleate cells, produce several hormones and growth factors associated with the development and maintenance of pregnancy (Schlafer et al.), their metabolic activity increases as pregnancy starts to require greater efforts from the animal. Consequently, the placental function must increase proportionally towards accompanying the fetal growth (Metcalfe et al., 1988), which implies a greater production of hormones, cytokines and growth factors (e.g., progesterone), and corpus luteum (its production has proven effective by trophoblastic cells (Reimers et al., 1985), placental lactogen (bPL) (Duello et al., 1986), pregnancy-associated glycoproteins (bPAG-1), bPAG-2, bPAG-3) (Roberts et al., 1995), and Transforming Growth Factor-beta (TGF-beta) (Munson et al., 1996).

The number of AgNORs expressed by binucleated cells increased only from the first to the second trimester, then remaining practically constant, which has led us to believe the activity of binucleated cells reaches its maximum peak in the second trimester and remains with this high metabolism until the end of pregnancy. This number was extremely higher than that observed in mononucleated trophoblastic cells, thus showing the intense metabolic activity of this cell. Both the number and size of AgNORs are highly variable within the nucleolus, according to the RNAr's transcriptional activity. A nucleolus with a low tax of ribosomal biogenesis is characterized by a unique and large NOR; however, the nucleus of activated cells exhibits a large number of small NORs (Derenzini \& Ploton). The size of the nucleolus, as well as the number and area of AgNORs reflect the activity of the cell and vary in function of cell type and stage of the cell cycle (Folkman \& Moscona, 1978; Lischwe et al., 1979; Williams et al., 1982).

Binucleated cells are formed through mitosis processes not followed by cytokinesis, i.e., the nucleus is duplicated with no division of cytoplasm (Bjõrkman, 1982). The nuclear division is finished by mitosis and the cytoplasm is never divided, which demonstrates its proliferative incapacity (Wimsatt, 1951). The high capacity for synthesis of nuclear material and proliferative incapacity have led us to infer the large amount of AgNORs found in those cells may be due to this formation process. On the other hand, if that was the only reason for the large amount of AgNORs, it should be constant throughout the pregnancy, which does not occur due to a significant increase from the first to the second trimesters. Morgan et al. (1989) demonstrated, through cytochemical methods, a sequential and differential production of proteins in binucleated cells throughout pregnancy, indicating they perform different functions according to the gestational stage. Moreover, binucleated cells are secretory, thus producing and transporting proteins to the maternal organism. One of their more effective representations is glycoprotein associated with pregnancy (bPAG) (Zoli et al., 1992; Klisch et al., 2000). Apart from these proteins, the production and secretion of placental lactogen (Wooding \& Flint, 1994), steroids and substances derived from the metabolism of prostaglandins (Klisch et al., 2000) are also associated with binucleate cells of the ruminant placenta. Such an intense activity of synthesis and secretion of substances can explain the large amount of AgNORs in the cells that, duly stimulated by growth and differentiation factors, can be responsible for the still unknown production of various substances in the placenta. Therefore, a relationship between the number of AgNORs in mononucleated trophoblastic cells and stage of pregnancy, and between numbers of AgNORs can be established. 
CARNEIRO, P. DOS S.; SASAhARA, T. H.C.; CARVALHO, H. J. C.; MIGLINO, M. A. \& GOMES, S. P. Determination of the relationship among cell proliferation, metabolic activity and stage of pregnancy by AgNORs as markers in bovine placenta. Int. J. Morphol., 39(5):1358-1364, 2021.

\section{CONCLUSIONS}

A relationship between the number of AgNORs in mononucleated trophoblastic cells and stage of pregnancy to which the evaluated tissues belong, as well as between the number of AgNORs in binucleated trophoblastic cells and their level of metabolic activity can be established. Such data become important as they are altered in placentas with pathological changes (which currently interest several research groups), or in placentas of compromised development from pregnancies of embryos manipulated in the laboratory. They also enable the obtaining of accurate information on the degree of proliferative and/or metabolic activity of the trophoblastic cells (mono and binucleate) evaluated and comparisons between the tissue from which they originated and the normality pattern established here.

ACKNOWLEDGEMENTS. The authors would like to thank the FAPESP and CAPES for support.

CARNEIRO, P. DOS S.; SASAHARA, T. H .C.; CARVALHO, H. J. C.; MIGLINO, M. A. \& GOMES, S. P. Determinación de la relación entre la proliferación celular, la actividad metabólica y la etapa de preñez por los AgNOR como marcadores en la placenta bovina. Int. J. Morphol., 39(5):1358-1364, 2021.

RESUMEN: Las Regiones Organizadoras de Nucléolos (NOR) se definen como componentes nucleolares que contienen proteínas argirofílicas teñidas selectivamente por métodos de plata (AgNOR). Varias investigaciones han demostrado que la cantidad y el área de AgNOR representan un parámetro importante de la cinética celular, ya que reflejan el nivel de actividad y proliferación celular. Este trabajo analiza la actividad funcional y la relación entre los días de preñez y la capacidad proliferativa de las células trofoblásticas mononucleadas y binucleadas de placentomas bovinos. Tanto el número como el tamaño de los AgNOR se determinaron en diferentes fases de la gestación mediante tinción con nitrato de plata en portaobjetos histológicos convencionales. Los resultados mostraron un aumento significativo (de 1 a 12 AgNOR) en el número de AgNORS por célula mononucleada trofoblástica en el tercer trimestre, con predominio de 4-6 AgNOR / célula. En el primer y segundo trimestre, el número osciló entre 1 y 9 AgNOR / célula, con predominio de 1-3 AgNOR. No se observaron diferencias significativas entre el 2do y 3er trimester; en el primer trimestre, en células binucleadas (19-27 y 10-18 AgNORs / célula, respectivamente) - este número fue superior a la cantidad registrada en células mononucleadas trofoblásticas en el mismo período. Por tanto, los AgNOR se pueden utilizar como marcadores del ciclo celular placentario proliferativo y se establece una relación entre el número de AgNOR y los días de gestación. Esta relación puede ser útil en el diagnóstico y pronóstico de varias patologías placentarias, incluidas las pérdidas de preñeces de embriones manipulados.

PALABRAS CLAVE: Regiones organizadoras nucleolares; Placenta; Estructuras celulares; Preñez.

\section{REFERENCES}

al-Abbass A. H. \& Schultz, R. L. Phagocytic activity of the rat placenta. J. Anat., 100(Pt. 2):349-59, 1966.

Baserga, R. The Biology of Cell Reproduction. Cambridge (MA), Harvard University Press, 1985.

Bjõrkman, N. Placentação. In: Dellman, H. D. \& Brown, E. M. Histologia Veterinária. Rio de Janeiro, Guanabara Koogan, 1982.

Derenzini, M. \& Ploton, D. Interphase nucleolar organizer regions in cancer cells. Int. Rev. Exp. Pathol., 32:149-92, 1991.

Derenzini, M. The AgNORs. Micron, 31(2):117-20, 2000.

Derenzini, M.; Pession, A. \& Trerè, D. Quantity of nucleolar silver-stained proteins is related to proliferating activity in cancer cells. Lab. Invest., 63(1):137-40, 1990.

Derenzini, M.; Pession, A.; Farabegoli, F.; Trerè, D.; Badiali, M. \& Dehan, P. Relationship between interphasic nucleolar organizer regions and growth rate in two neuroblastoma cell lines. Am. J. Clin. Pathol., 134(4):925-32, 1989.

Derenzini, M.; Sirri, V.; Trerè, D. \& Ochs, R. L. The quantity of nucleolar proteins nucleolin and protein B23 is related to cell doubling time in human cancer cells. Lab. Invest., 73(4):497-502, 1995.

Duello, T. M.; Byatt, J. C. \& Bremel, R. D. Immunohistochemical localization of placental lactogen in binucleate cells of bovine placentomes. Endocrinology, 119(3):1351-5, 1986.

Evans, H. E. \& Sack, W. O. Prenatal development of domestic and laboratory mammals: growth curves, external features and selected references. Zentralbl. Veterinarmed. C, 2(1):11-45, 1973.

Ferrell, C. L.; Garrett, W. N.; Hinman, N. \& Grichting, G. Energy utilization by pregnant and non-pregnant heifers. J. Anim. Sci., 42(4):937-50, 1976.

Folkman, J. \& Moscona, A. Role of cell shape in growth control. Nature, 273(5661):345-9, 1978.

Goodpasture, C. \& Bloom, S. E. Visualization of nucleolar organizer regions im mammalian chromosomes using silver staining. Chromosoma, 53(1):37-50, 1975.

Heitz, E. Ursache der gesetzmässigen Zahl, Lage, From und Grössepflanzlicher Nukleolen. Placenta, 12:775-844, 1931.

Ibsen, H. L. Prenatal growth in guinea-pigs with special reference to environmental factors affecting weight at birth. J. Exp. Zool. Part A, 51-9, 1928.

Klisch, K.; Hecht, W.; Pfarrer, C.; Schuler, G.; Hoffmann, B. \& Leiser, R. DNA content and ploidy level of bovine placentomal trophoblast giant cells. Placenta., 20(5-6):451-8, 1999a.

Klisch, K.; Pfarrer, C.; Schuler, G.; Hoffmann, B. \& Leiser, R. Tripolar acytokinetic mitosis and formation of feto-maternal syncytia in the bovine placentome: different modes of the generation of multinuclear cells. Anat. Embryol. (Berl.), 200:229-37, 1999b.

Klisch, K.; Schuler, G.; Miglino, M. A. \& Leiser, R. Genome multiplication in trophoblast giant cells of sheep, goat, water buffalo and deer: an image cytophotometric study. Reprod. Domest. Anim. 35(3-4): 145-8, 2000.

Leek, R. D.; Alison, M. R. \& Sarraf, C. E. Variations in the occurrence of silver-staining nucleolar organizer regions (AgNORs) in nonproliferating and proliferating tissues. J. Pathol., 165(1):43-51, 1991.

Lischwe, M. A.; Smetana, K.; Oslon, M. O. \& Busch, H. Proteins C23 and $\mathrm{B} 23$ are the major nucleolar silver staining proteins. Life Sci., 25(8):701-8, 1979.

McClintock, D. J. L. The relation of a particular chromosomal element to the development of the nucleoli in Zea mays. Zellforsch. Mikrosk. Anat., 21(2):294-326, 1934.

Metcalfe, J.; Stock, M. K. \& Barron, D. H. Maternal Physiology During Gestation. In: Knobil, E.; Neill, J.; Ewing, L. L.; Greenwald, G. S.; Markert, C. L. \& Pfaff, D. W. The Physiology of Reproduction. New York, Raven Press, 1988. pp.2145-76. 
Morgan, G.; Wooding, F. B.; Beckers, J. F. \& Friesen, H. G. An immunological cryo-ultrastructural study of a sequential appearance of proteins in placental binucleate cells in early pregnancy in the cow. J. Reprod. Fertil., 86(2):745-52, 1989.

Munson, L.; Wilhite, A.; Boltz, V. F. \& Wilkinson, J. E. Transforming growth factor beta in bovine placentas. Biol. Reprod., 55(4):748-55, 1996.

Neudeck, H.; Unger, M.; Hufnagl, P.; Eiben, B.; Peters, K.; Kalla, J.; Graf, R. \& Vogel, M. Villous cytotrophoblast proliferating potential in complete and partial hydatidiform mole: diagnostic value of silver-stained nucleolar organizer region (AgNOR)-associated proteins. Gen. Diagn. Pathol., 143(2-3):179-84, 1997.

Reimers, T. J.; Ullman, M. B. \& Hansel, W. Progesterone and prostanoid production by bovine binucleate trophoblastic cells. Biol. Reprod., 33(5):1227-36, 1985.

Reynolds, L. P.; Millaway, D. S.; Kirsch, J. D.; Infeld, J. E. \& Redmer, D. A. Growth and in-vitro metabolism of placental tissues of cows from day 100 to day 250 of gestation. J. Reprod. Fertil., 89(1):213-22, 1990.

Roberts, R. M.; Xies, S.; Nagel, R. J.; Low, B.; Green, J. \& Beckers, J. F. Glycoproteins of the aspartyl proteinase gene family secreted by the developing placenta. Adv. Exp. Med. Biol., 362:231-40, 1995.

Schlafer, D. H.; Fisher, P. J. \& Davies, C. J. The bovine placenta before and after birth: placental development and function in health and disease. Anim. Reprod. Sci., 60-61:145-60, 2000.

Suresh, U. R.; Chawner, L.; Buckley, C. H. \& Fox, H. Do AgNOR counts reflect cellular ploidy or cellular proliferation? A study of trophoblastic tissue. J. Pathol., 160(3):213-5, 1990.

Trerè, D.; Pession, A. \& Derenzini, M. The silver-stained proteins of interphasic nucleolar organizer regions as a parameter of cell duplication rate. Exp. Cell Res., 184(1):131-7, 1989.

Trerè, D.; Pession, A.; Montanaro, L.; Chieco, P. \& Derenzini, M. AgNOR protein expression and tumor growth rate of human carcinoma xenografts growing subcutaneously in nude mice. Eur. J. Histochem., 41 Suppl. 2:153-4, 1997.

Warwick, B. L. Prenatal growth of swine. J. Morphol., 46(1):59-84, 1928. Williams, M. A.; Kleinschmidt, J. A.; Krohne, G. \& Franke, W. W. Argyrophilic nuclear and nucleolar proteins of Xenopus laevis oocytes identified by gel electrophoresis. Exp. Cell Res., 137(2):341-51, 1982.

Wimsatt, W. A. Observations on the morphogenesis, cytochemistry, and significance of the binocleate giant cells of the placenta of ruminants. Am. J. Anat., 89(2):233-81, 1951.

Wooding, F. B. P. \& Flint, A. P. F. Placentation. In: Lamming, G. E. (Eds.). Marshall's Physiology of Reproduction. Dordrecht, Springer, 1994. pp.233-460.

Zoli, A. P.; Guilbault, L. A.; Delahault, P.; Ortiz, W. B. \& Beckers, J. F. Radioimmunoassay of a bovine pregnancy-associated glycoprotein in serum: its application for pregnancy diagnosis. Biol. Reprod., 46(1):8392, 1992.

\author{
Corresponding author: \\ Maria Angélica Miglino \\ Departamento de Cirurgia \\ Setor de Anatomia \\ Faculdade de Medicina Veterinária e Zootecnia \\ Universidade de São Paulo \\ Avenida Professor Orlando Marques de Paiva \\ 87, São Paulo \\ CEP: 05508-270 \\ BRAZIL
}

Email: miglino@usp.br

Received: 03-05-2021

Accepted: 02-07-2021 